\title{
Role of Endoscopy in osteolytic bone lesion management
}

Amro ahmed fouaad attia* MD.

\author{
* Corresponding Author: \\ Amro ahmed fouaad attia \\ amrfouad1980@yahoo.com
}

Received for publication April 12, 2021; Accepted June 04, 2021; Published online June 04, 2021.

Copyright The Authors published by Al-Azhar University, Faculty of Medicine, Cairo, Egypt. Users have the right to read, download, copy, distribute, print, search, or link to the full texts of articles under the following conditions: Creative Commons Attribution-Share Alike 4.0 International Public License (CC $B Y-S A$ 4.0).

doi: $10.21608 /$ aimj.2021.72157.1457

Department of Orthopedic, Faculty of Medicine, Al-Azhar University, Cairo, Egypt.

\begin{abstract}
Background: Although benign bone tumors, osteomyelitis, and locally malignant tumors are potential to be locally aggressive. Various treatment approaches, such as aspiration and injection, en bloc resection, open curettage, and other methods like sclerotherapy, and embolization are described but the most appropriate treatment should be selected after considering the risk of tumor recurrence and treatment complications. Endoscopic curettage (ESC) may be a less invasive alternative to open curettage for benign bone tumors, locally malignant swelling and osteomyelitis with minimal complications and good function output. Aim of the work: to describe the use of ESC for the treatment of bone lesions and report my clinical outcomes, including the rate of recurrence, time to consolidation, complications, and functional outcomes.

Patients and Methods: Between March 2017 and April 2019 patients 40 patients underwent ESC for the treatment of osteocytic lesion (benign , locally malignant and osteomyelitis ) at our unit with mean postoperative follow-up, 24 months. ESC was performed with extended curettage with or without bone graft or cement. The modified Neer classification And MSTS scoring system were used for follow up.

Results: By MSTS scoring system, 39 had have excellent results and the remaining 11 case had persistent pain duo to some reason. The modified Neer classifications was used for follow up. There is no relation between tumor size and recurrence.

Conclusion: Endoscopy plays a role of good visualization, assessment and decrease recurrent rate with good functional outcomes.

Keywords: Endoscopic curettage; Osteomylitis; Bone tumor; bone cyst; Endoscopy.
\end{abstract}

Disclosure: The authors have no financial interest to declare in relation to the content of this article. The Article Processing Charge was paid for by the authors.

Authorship: All authors have a substantial contribution to the article.

\section{INTRODUCTION}

Benign osteolytic lesions of bone occur in a wide range of clinical and pathological manifestations, ranging from the benign to the violent and destructive, with the ability to turn into high-grade malignancy and even produce metastases. ${ }^{1}$

Usually painless lesions, however, pathological fracture can be occurred in large lesions. Swelling, pain, and painful range of motion in lesion near the joint are documented. The goal of treatment is to alleviate these symptoms while still preventing the pathological fracture and to halt the lesion's progression. ${ }^{2}$

Marginal excision, wide block excision, and intralesional excision (curettage with or without burring or adjuvant therapy) have all been described as treatment options to achieve this therapeutic objectives. ${ }^{1,3,4}$
Endoscopic Management has been reported in few articles. It's been used to treat cystic lesions of the metatarsal, calcaneus, ${ }^{1,5}$ and talus, Murphey, MD. ${ }^{(6)}$ Endoscopic assisted curettage (ESAC) was proposed as an assisted method with curettage for the management of benign and low-grade malignant osteolytic lesions, as well as chronic osteomyelitis, and the surgical and clinical results of this therapy technique were reviewed.

\section{PATIENTS AND METHODS}

Patient

From march 2017 to April 2019 , we prospectively screened 40 patients (17 male $42.5 \%$ and 23 female $57.5 \%$ ) with benign, low grade chondrosarcoma lesions and chronic osteomylitis, in long and small bone of different anatomic locations and histopatological varieties (Table 1), all were treated at surgical oncology unit, Orthopedic department, AlAzhar University Hospitals. 


\begin{tabular}{|c|c|c|c|c|c|c|c|c|c|c|c|c|}
\hline No. & $\begin{array}{l}\text { Age/ } \\
\text { sex }\end{array}$ & PORTALS & Tum & $\begin{array}{c}\text { Pathol- } \\
\text { ogical } \\
\text { fracture }\end{array}$ & $\begin{array}{c}\text { Procedures with or } \\
\text { without bone graft, } \\
\text { site of bone graft }\end{array}$ & Fu & $\begin{array}{l}\text { Near to } \\
\text { articular } \\
\text { surface } \\
\end{array}$ & $\begin{array}{l}\text { Complicat- } \\
\text { ion }\end{array}$ & $\begin{array}{c}\text { Consolida- } \\
\text { tion time } \\
\text { In months } \\
\end{array}$ & $\begin{array}{c}\text { MS } \\
\text { TS }\end{array}$ & $\begin{array}{l}\text { Operative } \\
\text { time }\end{array}$ & Neer \\
\hline 1 & $25 \mathrm{~m}$ & 2 & Enchondroma / mcb & & $\begin{array}{c}\text { CURRE/ } \\
\text { BONE GRAFT, } \\
\text { DR }\end{array}$ & 12 & Yes & No & 5 & & 40 & $\mathrm{~A}$ \\
\hline 2 & $34 \mathrm{f}$ & 2 & Enchondroma / mcb & & $\begin{array}{c}\text { CURRE/ fibula } \\
\text { BONE GRAFT. DR }\end{array}$ & 22 & no & No & 4 & & 44 & B \\
\hline 3 & $24 \mathrm{f}$ & 2 & Enchondroma / mcb & & $\begin{array}{l}\text { CURRE/ BONE } \\
\text { GRAFT, DR }\end{array}$ & 44 & No & No & 5 & & 40 & A \\
\hline 4 & $17 \mathrm{f}$ & 2 & Enchondroma / mcb & & $\begin{array}{l}\text { CURRE/ BONE } \\
\text { GRAFT, DR }\end{array}$ & 51 & No & No & 3 & & 55 & A \\
\hline 5 & $22 \mathrm{~m}$ & 2 & Enchondroma / mcb & Yes & $\begin{array}{l}\text { CURRE/ FIXATION } \\
\text { BONE GRAFT, DR }\end{array}$ & 16 & No & No & 4 & & 38 & $\mathrm{~A}$ \\
\hline 6 & $19 f$ & 2 & Enchondroma/mtc & & $\begin{array}{l}\text { CURRE/ BONE } \\
\text { GRAFT, DR }\end{array}$ & 16 & No & No & 3 & & 40 & A \\
\hline 7 & $28 \mathrm{~m}$ & 3 & Enchondroma/mtc & & $\begin{array}{c}\text { CURRE/ fibular } \\
\text { BONE GRAFT, DR }\end{array}$ & 22 & yes & No & 5 & & 54 & A \\
\hline 8 & $9 \mathrm{f}$ & 3 & Enchondroma/ mtc & Yes & $\begin{array}{c}\text { CURRE/ } \\
\text { FIXATION, BONE } \\
\text { GRAFT,PROX. } \\
\text { ULNA }\end{array}$ & 19 & No & Fracture & 3 & & 60 & A \\
\hline 9 & $7 f$ & 3 & Enchondroma/mtc & & $\begin{array}{l}\text { CURRE/ BONE } \\
\text { GRAFT, PROX } \\
\text { ULNA }\end{array}$ & 19 & no & No & 3 & & 44 & A \\
\hline 10 & $22 f$ & 2 & Enchondroma/mtc & & $\begin{array}{l}\text { CURRE/ fibular } \\
\text { BONE GRAFT, }\end{array}$ & 34 & No & No & 7 & & 50 & $\mathrm{~B}$ \\
\hline 11 & $24 f$ & 2 & Enchondroma/mtc & Yes & CURRE/FIXATIO & 15 & No & $\begin{array}{c}\mathrm{S} \\
\text { INFECTIO } \\
\mathrm{N}\end{array}$ & 5 & & 55 & A \\
\hline 12 & $30 \mathrm{~m}$ & 2 & Enchondroma/mtc & & $\begin{array}{l}\text { CURRE/ BONE } \\
\text { GRAFT, DR }\end{array}$ & 25 & No & $\begin{array}{c}\text { Transient } \\
\text { radial nrve } \\
\text { palsy }\end{array}$ & 8 & & 60 & $\mathrm{~B}$ \\
\hline 13 & $20 f$ & 2 & Enchondroma/ph & Yes & $\begin{array}{l}\text { CURRE/ fixation } \\
\text { and BONE } \\
\text { GRAFT,PROX. } \\
\text { ULNA } \\
\end{array}$ & 28 & yes & No & 6 & & 50 & A \\
\hline 14 & $23 \mathrm{~m}$ & 2 & $\begin{array}{c}\text { Enchondroma/DISTAL } \\
\text { RADIUS }\end{array}$ & & CURRE/ GRAFT & 15 & No & $\begin{array}{l}\text { TENDENI } \\
\text { TIS }\end{array}$ & 7 & & 48 & $\mathrm{~B}$ \\
\hline 15 & $30 \mathrm{~m}$ & 2 & Enchondroma /ph & & $\begin{array}{c}\text { CURRE/ BONE } \\
\text { GRAFT, DR }\end{array}$ & 17 & No & No & 8 & & 50 & A \\
\hline 16 & $28 \mathrm{~m}$ & 3 & Enchondroma/ph & Yes & $\begin{array}{l}\text { CURRE/ fix and } \\
\text { bone graft,DR }\end{array}$ & 30 & no & $\begin{array}{l}\text { Pin tract } \\
\text { infection }\end{array}$ & 9 & & 49 & A \\
\hline 17 & $33 \mathrm{f}$ & 2 & Enchondroma/ph & & CURRE/GRAFT & 30 & no & No & 6 & & 50 & $\mathrm{~A}$ \\
\hline 18 & $24 \mathrm{M}$ & 2 & Enchondroma/ph & & CURRE/ GRAFT & 45 & No & No & 8 & & 40 & A \\
\hline 19 & $19 \mathrm{M}$ & 2 & Enchondroma/ph & & $\begin{array}{l}\text { CURRE/ BONE } \\
\text { GRAFT,PROX. } \\
\text { ULNA }\end{array}$ & 29 & No & No & 9 & & 44 & A \\
\hline 20 & $26 \mathrm{M}$ & 3 & Enchondroma/ph & & CURRE/ GRAFT & 35 & No & No & 6 & & 50 & $\mathrm{~A}$ \\
\hline 21 & $34 \mathrm{~F}$ & 4 & $\begin{array}{c}\text { CHRONIC } \\
\text { OSTEOMYLITIS PH }\end{array}$ & & CURRE/ cement & 12 & No & $\begin{array}{l}\text { LATE } \\
\text { RECURRE } \\
\text { NCE }\end{array}$ & 12 & & 120 & 0 \\
\hline 22 & $20 \mathrm{~F}$ & 4 & $\begin{array}{c}\text { CHRONIC } \\
\text { OSTEOMYLITIS DISTAL } \\
\text { FEMUR }\end{array}$ & & $\begin{array}{l}\text { CURRE/ } \\
\text { FIXATION, cement }\end{array}$ & 15 & Yes & No & -- & & 120 & -- \\
\hline 23 & $72 f$ & 3 & $\begin{array}{c}\text { Chondrosarcoma/ proximal } \\
\text { Humerus }\end{array}$ & & $\begin{array}{l}\text { CURRE/ cement and } \\
\text { fixation }\end{array}$ & 19 & no & No & --- & & 120 & -- \\
\hline 24 & $45 \mathrm{f}$ & 3 & $\begin{array}{l}\text { Chondrosarcoma distal } \\
\text { femur }\end{array}$ & & $\begin{array}{l}\text { CURRE/ cement and } \\
\text { fixation }\end{array}$ & 27 & Yes & No & -- & & 110 & ---- \\
\hline 25 & $34 f$ & 3 & $\begin{array}{c}\text { Giant cell tumor/ proximal } \\
\text { tibia }\end{array}$ & & $\begin{array}{c}\text { CURRE/ BONE } \\
\text { cement }\end{array}$ & 25 & yes & No & --- & & 70 & -- \\
\hline 26 & $33 \mathrm{f}$ & 3 & GCT/ distal femur & & $\begin{array}{c}\text { CURRE/ BONE } \\
\text { cement }\end{array}$ & 25 & Yes & No & -- & & 80 & -- \\
\hline 27 & $28 \mathrm{~m}$ & 3 & GCT/ proximal tibia & Yes & $\begin{array}{l}\text { CURRE/ fixation and } \\
\text { BONE cement }\end{array}$ & 40 & yes & No & -- & & 90 & -- \\
\hline 28 & $24 \mathrm{f}$ & 3 & GCT/ proximal tibia & & $\begin{array}{c}\text { CURRE/ BONE } \\
\text { cement }\end{array}$ & 25 & Yes & No & --- & & 100 & -- \\
\hline 29 & $41 \mathrm{~m}$ & 4 & $\begin{array}{c}\text { Fibrous dysplasia/ } \\
\text { PROXIMAL FEMURE }\end{array}$ & & $\begin{array}{c}\text { CURRE/ plate } \\
\text { fix,BONE GRAFT }\end{array}$ & 44 & no & $\begin{array}{l}\text { Deled } \\
\text { union }\end{array}$ & 10 & & 110 & $\mathrm{~B}$ \\
\hline 30 & $17 \mathrm{~F}$ & 3 & $\begin{array}{c}\text { Fibrous dysplasia /prox } \\
\text { HUM }\end{array}$ & & $\begin{array}{l}\text { CURRE/ BONE } \\
\text { GRAFT }\end{array}$ & 37 & yes & No & 12 & & 90 & $\mathrm{~B}$ \\
\hline 31 & $36 f$ & 3 & Aneurysmal/ proximal femur & & $\begin{array}{c}\text { CURRE/FIBULA } \\
\text { BONE GRAFT }\end{array}$ & 36 & yes & No & 6 & & 100 & B \\
\hline 32 & $29 \mathrm{~m}$ & 4 & Aneurysmal/ proximal femur & & $\begin{array}{c}\text { CURRE/ fixation } \\
\text { FIBULA BONE } \\
\text { GRAFT }\end{array}$ & 25 & yes & $\begin{array}{c}\text { Early } \\
\text { painful hip } \\
\text { ROM } \\
\end{array}$ & 8 & & 110 & $\mathrm{~B}$ \\
\hline 33 & $12 \mathrm{~m}$ & 2 & Aneurysmal/ distal radius & & $\begin{array}{c}\text { CURRE/ FIBULA } \\
\text { BONE GRAFT }\end{array}$ & 33 & & No & 4 & & 100 & B \\
\hline
\end{tabular}




\begin{tabular}{|c|c|c|c|c|c|c|c|c|c|c|}
\hline 34 & $21 f$ & 2 & Aneurysmal/ distal radius & $\begin{array}{l}\text { CURRE/ BONE } \\
\text { GRAFT }\end{array}$ & 11 & no & $\begin{array}{c}\text { EARLLY } \\
\text { STIFF } \\
\text { WRIST }\end{array}$ & 7 & 60 & A \\
\hline 35 & $35 \mathrm{~m}$ & 2 & Aneurysmal/ distal radius & $\begin{array}{l}\text { CURRE/ BONE } \\
\text { GRAFT }\end{array}$ & 13 & No & No & 11 & 66 & B \\
\hline 36 & $16 f$ & 3 & Aneurysmal/ proximal femur & $\begin{array}{l}\text { CURRE/FIBULA } \\
\text { BONE GRAFT }\end{array}$ & 24 & no & $\begin{array}{c}\text { Delayed } \\
\text { union }\end{array}$ & 22 & 70 & $\mathrm{C}$ \\
\hline 37 & $27 \mathrm{f}$ & 2 & Osteoblstoma/ PROX HUM & $\begin{array}{l}\text { CURRE/ BONE } \\
\text { GRAFT }\end{array}$ & 25 & yes & No & 7 & 66 & A \\
\hline 38 & $43 m$ & 2 & $\begin{array}{c}\text { Osteoblstoma/ PROX } \\
\text { FEMUR }\end{array}$ & CURR/ CEMENT & 18 & no & No & --- & 60 & -- \\
\hline 39 & $23 \mathrm{~m}$ & 2 & $\begin{array}{c}\text { RECURRENT } \\
\text { Osteoblstoma/PRO HUM }\end{array}$ & $\begin{array}{l}\text { CURRETAGE AND } \\
\text { CEMENT }\end{array}$ & 6 & yes & No & ---- & 90 & -- \\
\hline 40 & $22 \mathrm{f}$ & 2 & Osteoblstoma/ PROX HUM & $\begin{array}{l}\text { CURRETAGE AND } \\
\text { BONE GRAFT }\end{array}$ & 13 & yes & Recurrence & 14 & 66 & D \\
\hline
\end{tabular}

Table 1: Patients distribution.

The inclusion criteria of the cases includes both sex, age more than 7 years and lesion at small and long bone, and exclusion criteria were, less than 7 years old, high grade malignant lesions, and lesion at flat bone.

Full Tumor work up had done in most of cases and after biopsy, all were benign in nature and two case were low grade chondrosarcoma, and 2 cases of chronic osteomyelitis, some cases with pathological fracture (6 cases) at first presentation and we had to wait 4-5 weeks for the cavities to be closed to prevent fluid leakage. All 40 cases were treated with ESC (endoscopic curettage). The mean overall follow-up period was $(24.9-10.7)$ months.

\section{Surgical steps,}

All patients provided informed consent in accordance with the guidelines established by our hospital's ethical committee. Preoperative planning of surgical approaches, portals, type of anesthesia, and type of fixation are important. Regional or general anesthesia, and tourniquet with C-RM magnification, aspiration in some cases like aneurysmal bone cyst reveal bloody lesion (figure $\mathrm{d}$ and e), surgically safe mini incision were done with blunt dissection up to bone, drill bit 3.5 to incisions sites was protected by sleeve, blind curettage by curette (figure $\mathrm{f}$ ), or by universal incision for large or deep lesions, $\mathrm{H} 2 \mathrm{O} 2$ was used as adjuvant therapy (figure $3 \mathrm{~g}$ ) followed by An 2.7 or $4.0 \mathrm{~mm} 30$ angled camera at one portal and curette to another one and Finally the curette was replaced by high speed curette (figure $3 \mathrm{~h}$ ), to remove of all remnant membrane (fig 3 i), and allowing excision of 1 to $2 \mathrm{~mm}$ of the endosteum and bony septa and finally, Saline washing to remove any debris and endoscopic confirmation of all lesion boundaries. The degree of curettage of the lesion has been explicitly verified on gross inspection using an endoscopy, that was also verified using an X-ray magnifier and depending on hemorrhagic results. After the extended curettage of bone lesions, the bone graft was done utilizing autologous bone which was extracted from the graft donor site as ilium, distal radius, proximal ulna and or proximal tibia, or allograft Confirmation of bone graft filling space by endoscope and by X-ray magnifier. Fixation was done to protect the weak bone or in large metaphysical or diaphysis lesions. Bone cement in another cases of low grade sarcomas or osteomyelitis with or without antibiotic added as well.

\section{Postoperative evaluation}

Following surgery, the operated limb has been immobilized by a strip and taped, no weight bearing for 2 to 8 weeks according to lesion site and healing activity. All patients were prepared for postoperative follow up visits, which included radiographs and clinical evaluations every two weeks for the first two months, and then every three and six months following operation. The MSTS (Musculoskeletal Tumor Society Score) has been applicate to assess postoperative complications and functional recovery. ${ }^{7}$

A surgeon who is the A dependent examiner who performs the necessary clinical assessments including pain evaluation by pain visual analog scale (VAS), with ten points representing the most severe pain and joint range of motion. 2 views of $\mathrm{X}$ - ray for bone healing, graft resorption and lesion recurrence. Bone union has been described by medical evidence of pain relief in the lesion region and radiographic evidence of bone healing in both views, in the form of bone trabeculae crossing the fracture site. The criteria of Hou et al. to evaluate bone healing time after ESC, ${ }^{8}$ and Cyst consolidation. The updated Neer classification was used to classify the final assessment ${ }^{8,9}$ (Table 2). After bone healing, patients start doing physiotherapy to guard against stiffness that can develop during the period of splinting.

\begin{tabular}{|c|l|c|c|}
\hline A & $\begin{array}{l}\text { Healed Cyst filled with new } \\
\text { bone with } \\
\text { small radiolucent area }\end{array}$ & $\begin{array}{c}18 \\
\text { cases }\end{array}$ \\
\hline B & $\begin{array}{l}\text { Healed with a defect } \\
\text { Radiolucent area }\end{array}$ & $\begin{array}{c}(<50 \% \text { diameter }) \\
\text { with enough } \\
\text { cortical thickness }\end{array}$ & 9 \\
\hline C & $\begin{array}{l}\text { Persistent cyst Radiolucent } \\
\text { area }\end{array}$ & $\begin{array}{c}(\geqq 50 \% \text { diameter }) \\
\text { with thin cortical } \\
\text { rim }\end{array}$ & 2 \\
\hline D & $\begin{array}{l}\text { Recurrent cyst or Cyst } \\
\text { reappearing in the obliterated } \\
\text { area or in the increased } \\
\text { residual radiolucent area }\end{array}$ & Recurrence & 1 \\
\hline
\end{tabular}

Table 2: Modified Neer classification. Classification description details. 

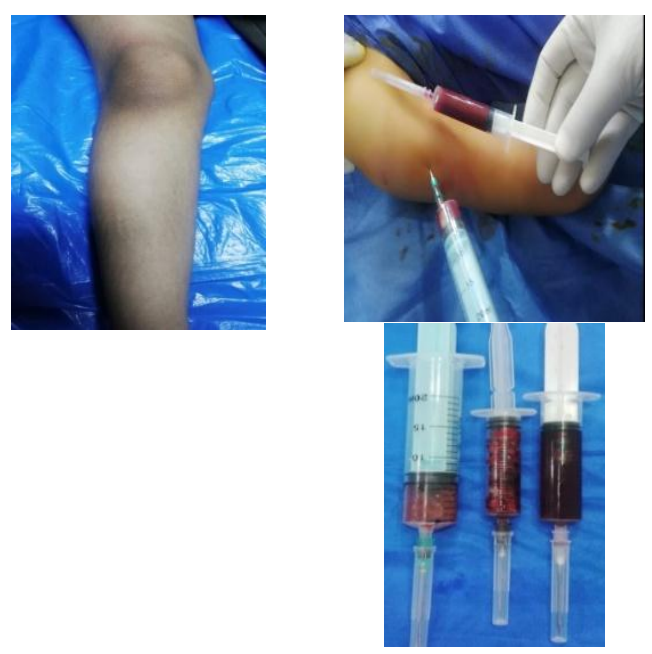

a
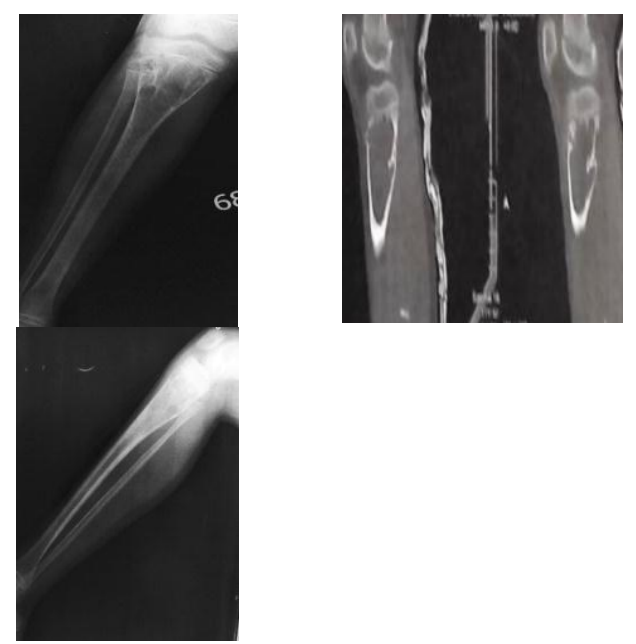

c

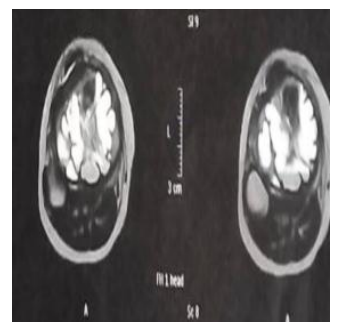

$\mathrm{e}$



g
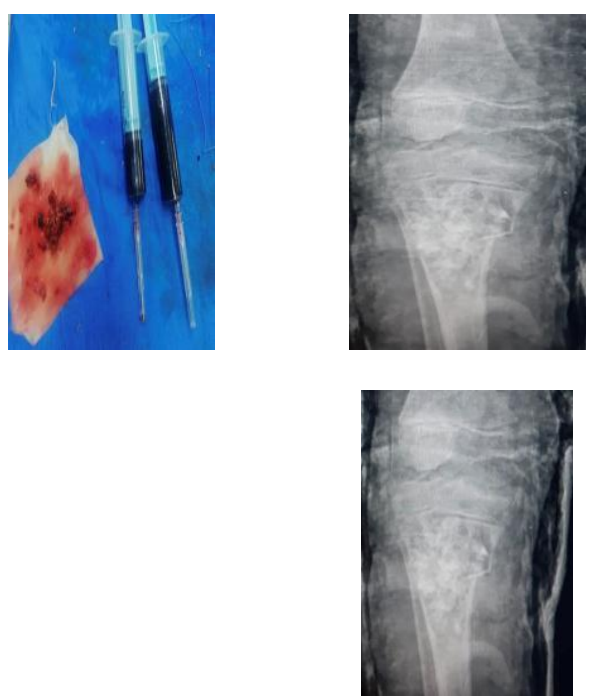

i

j

Fig. 1. Child 5 years old with aneurysmal bone cyst proximal tibia, ( $\mathrm{a}$ and $\mathrm{b})$ bone swelling and syringe aspiration, (c,d and e) x- ray, CT and MRI, (f) currettage, (g) $\mathrm{H}_{2} \mathrm{O}_{2}$ irrigation, (h) endoscopic curettage, (I) after curettage membrane, (j) post $\mathrm{x}$ ray.
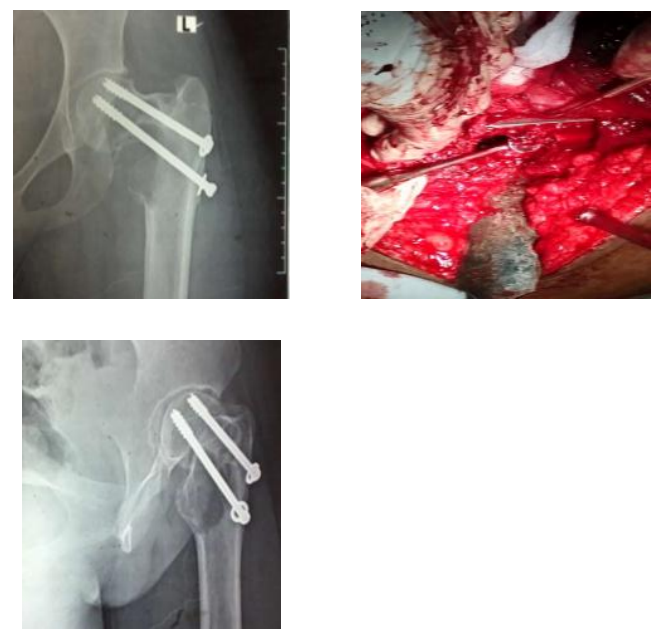

a

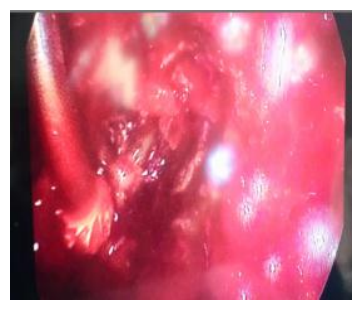

b

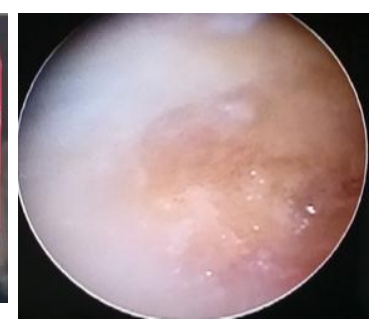

c 

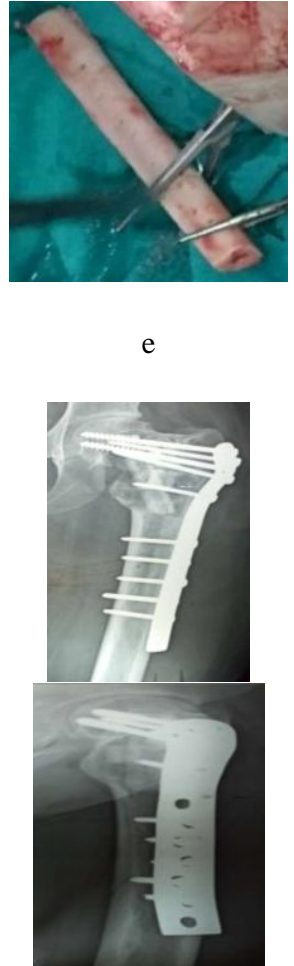

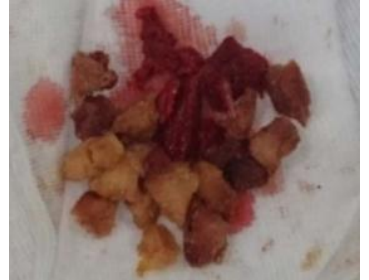

f

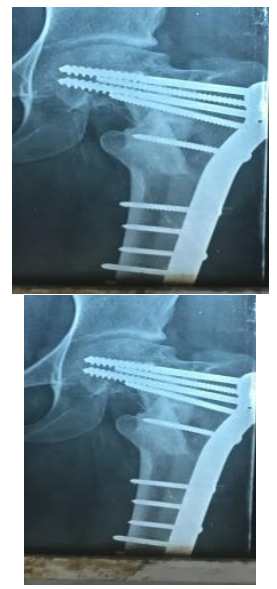

$\mathrm{h}$
Figure 2: Girl 13 years old with recurrent aneurysmal a bone cyst proximal femur treated previously by open curettage and screws fixation, (a) bone swelling, (b,c and d) endoscopic curettage, (e) fibular graft, (f) allograft, (g) post-operative $\mathrm{x}$-ray, (j) after 6 months $\mathrm{x}$-ray.

\section{RESULTS}

The average age was (26.9 _ 11.2), the median operative time was 68.9_26.3 Minutes (range $38 \mathrm{~min}$ to 120 minutes), and mean follow up was 24.9_10.7 months.

Size of the lesion is the key of portal numbers, among the 40 patients, an average of two portals were used. Four portals in 4 instances $(10 \%)$, three portals in 14 instances (35\%), and two portals in 22 instances $(55 \%)$. There were 30 cases treated by extended curettage with or without graft, and 10 patients were treated by curettage and cement application

Early follow up, Almost all patients were assisted by MSTS scoring system, it is simple and brave to assess physical function of both upper and lower limb tumors, with the exception of 11 patients who indicated persistent pain, excellent function following ESC became (MSTS = 30) and or stiff joints due to tumor recurrence in 2 patients, iatrogenic intraoperative fracture in one case, 2 patient with tendenitis, 2 patient with lesion near to the joint, 1 patients with delayed union, and 2 cases of superficial infection treated by antibiotics and one case of Transient radial nerve palsy treated by physiotherapy. During the follow-up period, the rate of recurrence following ESC was found in 2 case $(16.7 \%)$ one case of proximal humerus osteoblastoma, with a curative outcome achieved with repeated of open curettage and bone cement, and another one case of osteomyltis which are managed by revisions. The average time for consolidation after ESC in 28 cases was 7.3_3.95 months, and delayed union in 1 cases.

For 30 PT out of 40 instances, the updated Neer classifications of the final status following ESC were as follows. There were 28 instances of class A-B (healed cysts) and one instance of class $\mathrm{C}$ (persistent cysts) (evaluated by H.A.). And one case of recurrence and There is no relation between tumor size and recurrence.

\section{DISCUSSION}

I was given the surgical and clinical results of a reasonably large case series of patients treated with ESC for benign bone lesions, low-grade sarcomas, and osteomyelitis. With a tumor recurrence rate of 40 to $90 \%$, open curettage and defect reconstruction with bone graft or bone cement, as defined by Jaffe et al. ${ }^{10}$ remains the staple of modern therapy of benign bone lesions. In our study the recurrence rate was $(17 \%)$ less than open curettage. To enhance local control and reduce the rate of recurrence, high-speed burring or chemical therapy (including the usage of liquid nitrogen or polymethylmethacrylate) have been introduced as choices for the elimination of micro-residue tumors. ${ }^{11,12}$ Endoscopy has the benefit of precisely evaluating tumor resection by inspecting the bone marrow cavity directly for complete cyst removal (so if probable) without surrounding soft tissue damage and prevent other complications like excessive curettage or blind spot. ${ }^{13,14}$

The procedure is more aesthetically pleasing and less invasive compared to open procedures that it can perform via small holes, with preservation of the bone. ESC may be a suitable choice for the therapy of osteolytic bone lesions, despite the longer procedure time attributable to holes preparation and careful piece-by-piece curettage to prevent unnecessary curettage or residual tumor.

Since 1990, minimally invasive approaches to the therapy of enchondromas, unicameral bone cysts, and chondroblastomas were preferred. ${ }^{15,}{ }^{16}$ Moreover, Errani, et al. described their experiences with knee chondroblastoma endoscopic therapy allowing much visualization while avoiding violating the joint surface ${ }^{17}$ with good outcome in the form of healing time consolidation and recurrence rate as well as our study.

By activating healthy bone marrow directly, the main aim of ESC is to obtain full lesion resection and promote new bone formation. Curopsy, known as percutaneous limited curettage with endoscopy at the biopsy time, was identified by Reddy et al. ${ }^{18}$ as a feasible method to resecting the membrane lining the cyst with end results (a 16.7\% recurrence rate and a $7.3 \pm 3.95$ month period to bone healing). Our findings were similar to theirs $(10 \%$ recurrence rate following ESC). I hypothesized, like Curopsy, that ESC stimulated bone healing after tiny holes were 
penetrated, and that it was successful in eliminating tumor cell membranes. There is no rapid activation of tumor lesion after ESC and we suggest that ESC achieve total removal of residual tumor. We had a case of iatrogenic fracture during surgery and were treated by $\mathrm{K}$. wire fixation, at the moment; it is difficult to foresee pathological fractures with benign active bone tumors in pediatric, ${ }^{19}$ and or adults. We considered a lesion in the trochanteric area to be a contraindication to ESC in other research but I had a chance to perform fixation to prevent pathological fractures at first, followed by Esc extended curette and a fibular graft. In fact, we have a case of a transient radial nerve palsy, with good recovery. To prevent complications with ESC, preoperative preparation is critical, which includes determining the patient's location and portal positions in order to avoid neurovascular damage and pathological fractures.

Our research had certain limitations that should be recognized. First, to compare with open surgical interference, use of flexible camera rather than fixed one, long term follow up, finally, need a high learning curve to use ESC.

\section{CONCLUSION}

Benign bone tumors and low gad sarcomas are a group of neoplasms which is most common in children and young adults, but they can also appear later in life as well as osteomyelitis. Patient history and $\mathrm{x}$ ray are the gold issue for early diagnosis. Tumor work up is mandatory for lesion personality. For the majority treatment up to surgical interferences is only reported in symptomatic patients or where there is a risk of pathological fracture or malformation. Endoscopy play a role of good visualization, assessment and decrease recurrent rate with good functional outcomes.

\section{REFERENCES}

1 .Wong KC, Kumta SM, Tse LF, et al. Navigation endoscopic assisted tumor (NEAT) surgery for benign bone tumors of the extremities. Comput Aided Surg 2016;15:32-9.

2. Park HY, Yang SK, Sheppard WL, et al. Current management of aneurysmal bone cysts. Curr Rev Musculoskelet Med. 2016;9:435-44

3. Cummings JE, Smith RA and Heck RK Jr. Argon beam coagulation as adjuvant treatment after curettage of aneurysmal bone cysts: a preliminary study. Clin Orthop Relat Res. 2010;468:231-7. https://doi.org/10.1007/s11999-009- 0914-7.

4. Steffner RJ, Liao C, Stacy G, et al. Factors associated with recurrence of primary aneurysmal bone cysts: is argon beam coagulation an effective adjuvant treatment? J Bone Joint Surg Am. 2011;93:e1221-9. https://doi.org/10.2106/JBJS.J.01067.

5. Jordanov, M.I. The "rising bubble" sign: a new aid in the diagnosis of unicameral bone cyst. Skeletal Radiol. 2009;38:597-600.
6. Murphey, M.D., Choi, J.J., Kransdorf, M.J. et al, Imaging of osteochondroma: variants and complications with radiographic-pathologic correlation. Radiographics. 2000; 20:1407-34.

7. Enneking WF, Dunham W, Gebhardt MC, et al. A system for the functional evaluation of reconstructive procedures after surgical treatment of tumors of the musculoskeletal system. Clin Orthop Relat Res. 1993; (286): 241-6.

8. Hou HY, Wu K, Wang CT, et al. Treatment of unicameral bone cyst: a comparative study of selected techniques. J Bone Joint Surg Am. 2010;92:855-62. https://doi.org/10.2106/JBJS.I.00607.

9-. Neer CS, Francis KC, Marcove RC, et al. Treatment of unicameral bone cyst. A follow-up study of one hundred seventy-five cases. J Bone Joint Surg Am. 1966;48:731-45

10. Jaffe HL and Lichtenstein L. Solitary unicameral bone cyst with emphasis on the roentgen picture, the pathologic appearance and the pathogenesis. Arch Surg. https://doi.org/10.1001/archsurg.1942.

11. Ozaki T, Hillmann A, Lindner N, et al. Aneurysmal bone cysts in children. $J$ Cancer Res Clin Oncol. 1996; 122:767-9.

12. Peeters SP, Van der Geest IC, de Rooy JW, et al. Aneurysmal bone cyst: the role of cryosurgery as local adjuvant treatment. J Surg Oncol. 2009;100:719-24. https://doi.org/10.1002/jso.21410.

13. Choi Y, Kwak JM, Chung SH, et al. Tumor treated by endoscopy. Clin Orthop Surg. 2014;6:72-9. https://doi.org/10.4055/cios.2014.6.1.72.

14. Dietz JF, Kachar SM and Nagle DJ. Endoscopically assisted excision of digital enchondroma. Arthroscopy. 2007; 23:678.e1-4

15. Sekiya I, Matsui N, Otsuka T, et al. The treatment of enchondromas in the hand by endoscopic curettage without bone grafting. J Hand Surg Br. 1997; 22:230-4.

16. Okamoto H, Kobayashi M, Sekiya I, et al. Surgery for enchondroma on the fingers- endoscopic curettage. Central Jpn J Orthop Surg Traumatol. 2017;60:53-4.

17. Errani C, Traina F, Chehrassan M, et al. Minimally invasive technique for curettage of chondroblastoma using endoscopic technique. Eur Rev Med Pharmacol Sci. 2014;18:3394-8

18. Reddy KI, Sinnaeve F, Gaston CL, et al. Aneurysmal bone cysts: do simple treatments work? Clin Orthop Relat Res. 2014;472:1901-10. https://doi.org/10.1007/s11999-014-3513-1

19. Snyder BD, Hauser-Kara DA, Hipp JA, et al. Predicting fracture through benign skeletal lesions with quantitative computed tomography. J Bone Joint Surg Am. 2006; 88:55-70 